\title{
High-density lipoprotein $\left(\mathrm{HDL}_{3}\right)$-associated $\alpha$-tocopherol is taken up by HepG2 cells via the selective uptake pathway and resecreted with endogenously synthesized apo-lipoprotein B-rich lipoprotein particles
}

\author{
Daniel GOTI, Helga REICHER, Ernst MALLE, Gerhard M. KOSTNER, Ute PANZENBOECK and Wolfgang SATTLER ${ }^{1}$ \\ Department of Medical Biochemistry, University of Graz, Harrachgasse 21, 8010 Graz, Austria
}

$\alpha$-Tocopherol $(\alpha \mathrm{TocH})$ is transported in association with lipoproteins in the aqueous milieu of the plasma. Although up to $50 \%$ of circulating $\alpha \mathrm{TocH}$ is transported by high-density lipoproteins (HDLs), little is known about the mechanisms of uptake of HDL-associated $\alpha$ TocH. During the current study, human apolipoprotein (apo)E-free HDL subclass $3\left(\mathrm{HDL}_{3}\right)$ labelled with $\left[{ }^{14} \mathrm{C}\right] \alpha$ TocH was used to investigate uptake mechanisms of $\mathrm{HDL}_{3}$-associated $\alpha \mathrm{TocH}$ by a permanent hepatoblastoma cell line (HepG2). $\mathrm{HDL}_{3}$-associated $\alpha \mathrm{TocH}$ was taken up independently of $\mathrm{HDL}_{3}$ holoparticles in excess of apoA-I comparable with the non-endocytotic delivery of cholesteryl esters to cells termed the 'selective' cholesteryl ester uptake pathway. Experiments with unlabelled $\mathrm{HDL}_{3}$ demonstrated net mass transfer of $\alpha \mathrm{TocH}$ to HepG 2 cells. Time-dependent studies with $\left[{ }^{14} \mathrm{C}\right] \alpha \mathrm{TocH}-$ labelled $\mathrm{HDL}_{3}$ revealed tracer uptake in 80-fold excess of apoA$\mathrm{I}$ and in 4-fold excess of cholesteryl linoleate. In addition to HLDs, low-density lipoprotein (LDL)-associated $\alpha \mathrm{TocH}$ was also taken up in excess of holoparticles, although to a lesser extent. These findings were confirmed with unlabelled lipoprotein preparations, in which $\mathrm{HDL}_{3}$ displayed a 2- to 3-fold higher $\alpha \mathrm{TocH}$ donor efficiency than LDLs (lipoproteins adjusted for equal amounts of $\alpha \mathrm{TocH}$ ). An important factor affecting particleindependent uptake of $\alpha \mathrm{TocH}$ was the cellular cholesterol content (a 2-fold increase in cellular cholesterol levels resulted in a 2.3fold decrease in uptake). Pulse-chase studies demonstrated that some of the $\mathrm{HDL}_{3}$-associated $\alpha$ TocH taken up independently of holoparticle uptake was resecreted along with a newly synthesized apoB-containing lipoprotein fraction.

\section{INTRODUCTION}

Vitamin E is a generic term for the naturally occurring tocopherols and tocotrienols, and, of these, $\alpha$-tocopherol $(\alpha \mathrm{TocH})$ has the highest biological activity [1]. In vivo, vitamin $\mathrm{E}$ is an important constituent of cellular membranes in all tissues, acting as a major lipid-soluble chain-breaking antioxidant and thereby protecting unsaturated fatty acid residues against (per)oxidative damage [2]. It is an essential nutrient, and the major symptoms of vitamin E deficiency are neurological dysfunction, muscular weakness and reproductive failure [3,4].

Dietary vitamin $\mathrm{E}$ is taken up by intestinal cells and resecreted in chylomicrons in proportion to the concentration of the naturally occurring tocopherols in the diet [5]. In vivo studies have demonstrated preferential enrichment of very-low-density lipoproteins with $\alpha \mathrm{TocH}$ over $\gamma \mathrm{TocH}$, a process facilitated by an hepatic $\alpha$-TocH-binding/transfer protein (reviewed in ref. [6]). In the fasting state, $\alpha \mathrm{TocH}$ is distributed between the very-low-, low- and high-density lipoprotein (VLDL, LDL and HDL respectively) fraction in a $1: 1.9: 1.4$ proportion [7]. However, this distribution is dependent on the relative lipoprotein content of the plasma samples analysed [7]. In the fed state, $\alpha$ TocH uptake by peripheral tissues may occur by different pathways. One of the first steps contributing to tissue supply with $\alpha$ TocH is lipoprotein lipase-mediated hydrolysis of triacylglycerol-rich lipoproteins [8]. Both the lipolytic activity and the bridging function of lipoprotein lipase appear to contribute to lipid transfer from lipoproteins to cells [9] or tissues [10]. Secondly, tissues may partially acquire LDL-associated $\alpha$ TocH via the LDL-receptor pathway. However, the quantitative importance of this pathway is not entirely clear, since Watanabe heritable hyperlipidaemic rabbits (lacking functional LDL receptors) have normal tissue $\alpha$ TocH concentrations [11]. Finally $\alpha$ TocH transfer between lipoproteins and tissues may contribute to the maintenance of tissue $\alpha$ TocH levels.

As a result of the oxidative theory of atherogenesis [12], LDLassociated $\alpha \mathrm{TocH}$ has received much attention, especially with regard to its anti- and/or pro-oxidative properties during radicalinitiated lipid peroxidation of LDL $[13,14]$. HDL-associated $\alpha \mathrm{TocH}$ has received much less attention, a surprising fact since $30-50 \%$ of circulating $\alpha \mathrm{TocH}$ is carried within the HDL fraction $[7,10]$. Consequently, the mechanisms of HDL-associated $\alpha \mathrm{TocH}$ uptake are poorly understood and have been attributed to nonspecific receptor-independent transfer mechanisms [15]. In contrast with LDL-associated lipids, which are primarily metabolized in association with intact lipoprotein particles via the LDLreceptor pathway, HDL lipids [particularly cholesteryl esters (CEs)] are turned over by three different metabolic pathways: (i) metabolism of intact HDL particles (holoparticle uptake [16]); (ii) CE-transfer protein (CETP)-mediated exchange [17]; (iii) a pathway termed selective uptake [18]. 'Selective' refers to the fact that CEs are extracted from the HDL particle and internalized via scavenger receptor BI (SR-BI)-mediated mechanisms without concomitant endocytosis of the remaining HDL particle [19].

As 'selective uptake' has turned out to be an important metabolic pathway for HDL-associated lipids, we investigated whether the uptake of HDL-associated $\alpha$ TocH by HepG2 cells is

Abbreviations used: $\alpha \mathrm{TocH}, \alpha$-tocopherol; apo, apolipoprotein; CE, cholesteryl ester; CETP, cholesteryl ester-transfer protein; Ch, cholesterol; DMEM, Dulbecco's modified Eagle's medium; FCS, fetal calf serum; HDL, high-density lipoprotein; LPDS, lipoprotein-deficient serum; NEM, Nethylmaleimide; SR-BI, scavenger receptor BI; TBS, Tris-buffered saline; VLDL, very-low-density lipoprotein.

To whom correspondence should be addressed (e-mail wolfgang.sattler@kfunigraz.ac.at). 
mediated in the same way as selective uptake of HDL-associated CEs; both the polarity and topographical location [20] of $\alpha \mathrm{TocH}$ within the HDL particle are compatible with such a concept. Subsequently we addressed the question of whether there are regulatory steps in common with the selective uptake of HDLassociated CEs, and, if uptake does occur via the selective uptake pathway, is $\alpha$ TocH resecreted along with endogenously synthesized lipoproteins? We finally looked at whether there are differences between $\mathrm{HDL}_{3}$ and LDL with regard to their $\alpha \mathrm{TocH}$ donor efficacy.

\section{EXPERIMENTAL \\ Materials}

Chloroquine, monensin, $\mathrm{NaN}_{3}, \mathrm{KNO}_{3}$ and egg yolk lecithin were from Sigma, Vienna, Austria. Methanol, propan-2-ol, hexane, $\mathrm{KBr}, \mathrm{Na}_{2} \mathrm{MoO}_{4}$ and $\left(\mathrm{NH}_{4}\right)_{2} \mathrm{VO}_{3}$ were obtained from Merck, Vienna Austria. LC-18 reversed-phase HPLC columns were obtained from Supelco, Vienna, Austria $(250 \mathrm{~mm} \times 4.5 \mathrm{~mm})$ or Chrompack, Vienna Austria $(200 \mathrm{~mm} \times 2 \mathrm{~mm})$. $\left[{ }^{14} \mathrm{C}\right] \alpha$ TocH was a gift from Dr. W. Steiling, Henkel Co., Dusseldorf, Germany. All other radiochemicals were obtained from NEN, Vienna, Austria. Consumables used during cell culture studies were obtained from BioWhitaker or Costar Vienna, Austria. PD-10 size-exclusion columns were from Pharmacia, Uppsala, Sweden, and immunoprecipitin was obtained from Gibco, Paisley, Scotland, U.K. All other materials were purchased from Merck, Darmstadt, Germany as analytical-grade reagents.

\section{Lipoprotein preparation}

Human LDL and apolipoprotein (apo)E-free $\mathrm{HDL}_{3}$ were prepared by density-gradient ultracentrifugation of plasma obtained from normolipidaemic donors in a TL120 tabletop ultracentrifuge (at $r_{\mathrm{av}} \approx 350000 \mathrm{~g}$; Beckman, Vienna, Austria) [21] or by preparative discontinuous ultracentrifugation [22]. $\mathrm{HDL}_{3}$ was recovered from the tubes, and excess $\mathrm{KBr}$ was removed by sizeexclusion chromatography on PD-10 columns. SDS/PAGE revealed the presence of apoA-I as the major apolipoprotein. Lipoprotein-deficient serum (LPDS) was prepared by standard techniques [23].

\section{Lipoprotein labelling}

$\mathrm{HDL}_{3}$ labelling with $\left[\right.$ cholesteryl-1,2,6,7- $\left.{ }^{3} \mathrm{H}\right]$ linoleate $\left(\left[{ }^{3} \mathrm{H}\right]-\right.$ Ch18:2), was achieved by CETP-catalysed transfer from donor liposomes [24]. Briefly, $200 \mu \mathrm{Ci}$ of $\left[{ }^{3} \mathrm{H}\right] \mathrm{Ch} 18: 2$ and $80 \mu \mathrm{g}$ of egg yolk lecithin were dried under argon and sonicated in $1 \mathrm{ml}$ of PBS, pH 7.4. $\mathrm{HDL}_{3}(1 \mathrm{ml}$, containing $2-5 \mathrm{mg}$ of protein), LPDS $(1 \mathrm{ml}$, as a source of CETP) and PBS $(1 \mathrm{ml})$ were added. The mixture was incubated overnight under argon at $37^{\circ} \mathrm{C}$ in a shaking water-bath. For the sake of comparability, labelling of $\mathrm{HDL}_{3}$ with $\left[1,2,6,7-{ }^{3} \mathrm{H}\right]$ cholesterol $\left(\left[{ }^{3} \mathrm{H}\right] \mathrm{Ch}\right)$ or D- $\alpha$-5-methyl $\left[{ }^{14} \mathrm{C}\right]-$ tocopherol $\left(\left[{ }^{14} \mathrm{C}\right] \alpha \mathrm{TocH}\right)$ was performed exactly as described for $\left[{ }^{3} \mathrm{H}\right] \mathrm{Ch} 18: 2$. Subsequently the labelled $\mathrm{HDL}_{3}$ was reisolated in a TLX120 bench-top ultracentrifuge in a TLA100 rotor (Beckman) as described [24]. The $\mathrm{HDL}_{3}$ band was aspirated and desalted by size-exclusion chromatography on PD-10 columns. This labelling procedure resulted in specific radioactivities of $0.5-3,5-7$ and 8-10 c.p.m./ng of $\mathrm{HDL}_{3}$ protein for $\left[{ }^{14} \mathrm{C}\right] \alpha \mathrm{TocH},\left[{ }^{3} \mathrm{H}\right] \mathrm{Ch} 18: 2$ and $\left[{ }^{3} \mathrm{H}\right] \mathrm{Ch}$ respectively.

To compare transfer of $\left[{ }^{14} \mathrm{C}\right] \alpha \mathrm{T}$ ocH and net mass transfer of endogenous lipoprotein associated $\alpha \mathrm{TocH}$ to HepG2 cells, $\mathrm{HDL}_{3}$ ( $1.5 \mathrm{mg}$ of protein, final volume $2 \mathrm{ml}$ in PBS) or LDL ( $0.6 \mathrm{mg}$ of protein, final volume $2 \mathrm{ml}$ in PBS) was labelled by direct injection of increasing specific radioactivities of an ethanolic $\left[{ }^{14} \mathrm{C}\right] \alpha \mathrm{TocH}$ solution and incubation at $37^{\circ} \mathrm{C}(3 \mathrm{~h}$; under argon; shaking water-bath). Non-lipoprotein-associated $\left[{ }^{14} \mathrm{C}\right] \alpha \mathrm{TocH}$ was removed by size-exclusion chromatography on PD-10 columns. Lipids were extracted and analysed by radio-HPLC as described below. To allow simultaneous quantification of tracer and endogenous $\alpha \mathrm{TocH}$, the radiometric detector was preceded by a fluorescence detector. To compare transfer of tracer and endogenous $\alpha \mathrm{TocH}, \mathrm{HDL}_{3}$ and LDL preparations with similar specific radioactivities were chosen from the set of labelled lipoproteins prepared as described above.

$\mathrm{HDL}_{3}$ and LDL were iodinated as described by Sinn et al. [25] using $N$-Br-succinimide as the oxidizing agent. Routinely $1 \mathrm{mCi}$ of $\mathrm{Na}^{125} \mathrm{I}$ was used to label either $5 \mathrm{mg}$ of $\mathrm{HDL}_{3}$ protein or $2 \mathrm{mg}$ of LDL protein. This procedure resulted in specific radioactivities of between 300 and 450 d.p.m./ng of protein. Lipid-associated radioactivity was always less than $3 \%$ of total radioactivity. No cross-linking or fragmentation of apoA-I or apoB-100 due to the iodination procedure was detected by SDS/PAGE and subsequent autoradiography.

\section{$\alpha$ TocH analysis}

Cellular lipids were extracted with hexane/propan-2-ol $(3: 2$, $\mathrm{v} / \mathrm{v})$ at $25^{\circ} \mathrm{C}$ (30 min on a plateau shaker) [26]. The lipid extracts were dried under argon, redissolved in $200 \mu \mathrm{l}$ of methanol and analysed by reversed-phase HPLC on an LC-18 column $(25 \mathrm{~cm} \times$ $0.46 \mathrm{~cm})$ with methanol as the mobile phase $(1 \mathrm{ml} / \mathrm{min})$ and fluorescence detection (excitation and emission wavelengths 292 and $335 \mathrm{~nm}$ respectively). $\alpha$ TocH was quantified by peak-area comparison with external standards of known concentration. The concentration of freshly prepared standards was estimated photometrically $\left(\epsilon_{292}=3467 \mathrm{M}^{-1} \cdot \mathrm{cm}^{-1}\right)$.

Reversed-phase HPLC of radiolabelled $\alpha \mathrm{TocH}$ and metabolites was performed on a Chrompack LC-18 column $(250 \mathrm{~mm} \times$ $2 \mathrm{~mm})$ with methanol/water $(98: 2, \mathrm{v} / \mathrm{v})$ as the mobile phase (200 $\mu \mathrm{l} / \mathrm{min})$, essentially as described [27]. Radiolabelled compounds were detected with a Radiomatic Flo-One radiometric HPLC detector (Packard-Canberra; channel set at 0-156 keV) which was preceded by a fluorescence detector to allow simultaneous detection of labelled and unlabelled compounds. Liquidscintillation fluid flow rate was set to $1 \mathrm{ml} / \mathrm{min}$.

\section{Cell culture studies}

Human hepatoma HepG2 cells [28] were seeded in $35 \mathrm{~mm}$ multiwell culture plates or on $35 \mathrm{~mm}$ Petri dishes and cultured under standard conditions $\left(37^{\circ} \mathrm{C} ; 5 \% \mathrm{CO}_{2} ; 95 \%\right.$ humidity) in Dulbecco's modified Eagle's medium (DMEM) containing fetal calf serum (FCS; $10 \%, \mathrm{v} / \mathrm{v})$, streptomycin $(40 \mu \mathrm{g} / \mathrm{ml})$ and penicillin (40 units $/ \mathrm{ml}$ ). When the cells were $70-80 \%$ confluent, the monolayers were washed twice with Tris-buffered saline (TBS, pH 7.4) and conditioned in fresh DMEM containing either FCS $(10 \%, v / v)$ or LPDS $(10 \%, v / v)$ for $24 \mathrm{~h}$. The cells were then washed again (DMEM, $2 \times$ ) and the uptake assays were initiated in DMEM containing either FCS or LPDS.

For uptake studies, HepG2 cells were incubated for the indicated times with the corresponding radiolabelled $\mathrm{HDL}_{3}$ preparations in the absence or presence of excess (20-fold) unlabelled $\mathrm{HDL}_{3}$, and, where noted, the appropriate amount of metabolic inhibitor or competitor. Thereafter the tissue culture plates were placed on ice, the medium was removed and the cells were washed twice with ice-cold TBS containing BSA $(2 \mathrm{mg} / \mathrm{ml})$ followed by another two washes with ice-cold TBS. Cells were 
lysed by treatment with $1.0 \mathrm{ml}$ of $\mathrm{NaOH}\left(0.3 \mathrm{M} ; 25^{\circ} \mathrm{C} ; 30 \mathrm{~min}\right.$ [23]). Protein was measured by the method of Lowry et al. [29]. Degradation of ${ }^{125}$ I-lipoproteins was measured as described [30].

Incubation in the presence of metabolic inhibitors was performed as follows: HepG2 cells were incubated as described above in DMEM containing 10\% LPDS. Cells were pretreated with monensin $(5 \mu \mathrm{M}$; overnight $)$, colchicine $(10 \mu \mathrm{M} ; 2 \mathrm{~h})$ or acrylamide $(5 \mathrm{mM} ; 6 \mathrm{~h})$. Bafilomycin A $(250 \mathrm{nM}), \mathrm{KNO}_{3}$ $(50 \mathrm{mN}), \mathrm{NaN}_{3}(1 \mathrm{mM}),\left(\mathrm{NH}_{4}\right)_{2} \mathrm{VO}_{3}(50 \mu \mathrm{M})$ and $\mathrm{Na}_{2} \mathrm{MoO}_{4} \times 2$ $\mathrm{H}_{2} \mathrm{O}(250 \mu \mathrm{M})$ were used as ATPase inhibitors and left on cells for $60 \mathrm{~min}$.

To facilitate the comparison of results obtained with ${ }^{125} \mathrm{I}-$ $\mathrm{HDL}_{3}, \quad\left[{ }^{14} \mathrm{C}\right] \alpha \mathrm{TocH}-\mathrm{HDL}_{3}, \quad\left[{ }^{3} \mathrm{H}\right] \mathrm{Ch} 18: 2-\mathrm{HDL}_{3}$ and $\left[{ }^{3} \mathrm{H}\right] \mathrm{Ch}-$ $\mathrm{HDL}_{3}$, selective $\mathrm{HDL}_{3}$-lipid uptake is expressed as apparent $\mathrm{HDL}_{3}$ particle uptake as suggested by Pittman et al. [31]. Apparent $\mathrm{HDL}_{3}$ particle uptake is expressed in terms of $\mathrm{HDL}_{3}$ protein (calculated on the basis of the specific radioactivity of the corresponding $\mathrm{HDL}_{3}$ preparations used) that would be necessary to deliver the observed amount of tracer. These calculations are performed to compare uptake of ${ }^{125} \mathrm{I}$ and ${ }^{3} \mathrm{H}$ tracers on the same basis.

\section{Resecretion of $\alpha \mathrm{Toch}$}

HepG2 cells were cultured on $60 \mathrm{~mm}$ Petri dishes $(5 \mathrm{ml}$ of medium; standard conditions as described above) and incubated in DMEM containing $10 \%$ LPDS $12 \mathrm{~h}$ before the experiments. Cells were washed with PBS (three times) and received fresh medium containing $500 \mu \mathrm{g}$ of $\left[{ }^{14} \mathrm{C}\right] \alpha \mathrm{TocH}-\mathrm{HDL}_{3}$ protein (120 min) and cholesterol (added in $10 \mu \mathrm{l}$ of ethanol) to down-regulate the HepG2 LDL-receptor expression to block reuptake of newly synthesized lipoproteins. The $\mathrm{HDL}_{3}$-containing medium was then removed and the cells were treated with trypsin $\left(0.05 \% ; 37^{\circ} \mathrm{C} ; 3 \mathrm{~min}\right)$ to remove membrane-bound $\mathrm{HDL}_{3}$ particles and washed with PBS [24]. Subsequently, $3 \mathrm{ml}$ of medium containing $50 \mu \mathrm{g}$ of cholesterol $/ \mathrm{ml}$ was left on the cells for a further 3 or $6 \mathrm{~h}$. After this incubation, the medium was removed and the cellular supernatant was adjusted to a density of $1.24 \mathrm{~g} / \mathrm{ml}$ by the addition of solid $\mathrm{KBr}$. A discontinuous density gradient was established as follows. The density-adjusted medium was overlayered with $3 \mathrm{ml}$ of $1.08 \mathrm{~g} / \mathrm{ml}, 3 \mathrm{ml}$ of $1.05 \mathrm{~g} / \mathrm{ml}$ and $1 \mathrm{ml}$ of PBS $(10 \mathrm{mM})$ to give a final volume of $10 \mathrm{ml}$. The samples were centrifuged in a Beckman SW-41 rotor at $\boldsymbol{g}_{\max }=270000(40000 \mathrm{rev} . / \mathrm{min})$ for $24 \mathrm{~h}\left(15^{\circ} \mathrm{C}\right)$. Fractions of volume $1 \mathrm{ml}$ were removed from the top of the tube, transferred to preweighed Eppendorf tubes and weighed again to estimate the density of the down-loaded fractions. The radioactivity in the fractions was measured on a $\beta$-counter. The cells were lysed in $0.3 \mathrm{M} \mathrm{NaOH}$ on an orbital shaker $\left(2 \mathrm{ml} ; 1 \mathrm{~h} ; 25^{\circ} \mathrm{C}\right)$ to measure the protein content and the remaining internalized radioactivity.

\section{Immunoprecipitation of apoB-100}

In parallel with the experiments described above, HepG2 cells were pulse-labelled with radioactive methionine, and the cellular supernatant was subjected to ultracentrifugation [32]. A $56 \mathrm{~cm}^{2}$ Petri dish was incubated in methionine-free DMEM for $2 \mathrm{~h}$, and then pulse-labelled in the presence of $\left[{ }^{35} \mathrm{~S}\right]$ methionine $(150 \mu \mathrm{Ci} /$ dish) for $2 \mathrm{~h}$. Cells were washed as described above and further incubated in the presence of methionine-containing DMEM for $3 \mathrm{~h}$. The cellular supernatant was removed and subjected to ultracentrifugation in the discontinuous density gradient in an SW41 rotor exactly as described above. Fractions of volume $1 \mathrm{ml}$ were down-loaded from the top of the tube and immunoprecipitated as follows. A sham precipitation was per- formed with non-immune rabbit $\operatorname{IgG}(50 \mu \mathrm{g}$ of $\mathrm{IgG} / \mathrm{ml} ; 3 \mathrm{~h}$; $25^{\circ} \mathrm{C}$; end-over-end shaker), and then $150 \mu \mathrm{l}$ of immunoprecipitin was added and incubated for a further $30 \mathrm{~min}$ as described [32,33]. The samples were then centrifuged at $15000 \mathrm{~g}$ (13000 rev./min) $\left(25^{\circ} \mathrm{C} ; 3 \mathrm{~min}\right)$. ApoB-100-containing lipoproteins secreted into the medium were precipitated with a rabbit polyclonal anti-(human LDL) IgG (20 $\mu \mathrm{g}$ of $\mathrm{IgG} /$ fraction) and incubated as described for the sham precipitation. The pellet was washed, resuspended in $50 \mu 1$ of O'Ferrals buffer [63 mM Tris/ $\mathrm{HCl}, \mathrm{pH} 6.8,10 \%$ (v/v) glycerol, $5 \%$ (v/v) 2-mercaptoethanol, $25 \%$ (w/v) SDS] and incubated at $95^{\circ} \mathrm{C}(5 \mathrm{~min})$. The immunoprecipitated apoB-100-containing lipoproteins were separated by SDS/PAGE $\left(3-7 \%\right.$ gradient gels; $\left.25 \mathrm{~mA} / \mathrm{gel}, 4{ }^{\circ} \mathrm{C}\right)$. Gels were then fixed in $30 \%(\mathrm{w} / \mathrm{v})$ trichloroacetic acid, washed in methanol containing acetic acid $(5 \%, v / v)$ and soaked in Amplify (30 min). Autoradiography of dried gels $\left(48 \mathrm{~h}\right.$ at $\left.-70^{\circ} \mathrm{C}\right)$ was performed on Cronex Hyperfilm [34].

\section{RESULTS}

\section{$\alpha$ Toch content of $\mathrm{HDL}_{3}$ and LDL}

Lipoproteins were analysed for $\alpha \mathrm{TocH}$ content immediately after isolation and revealed a content of $1.8 \pm 0.81\left(\mathrm{HDL}_{3}\right.$, five preparations) and $3.7 \pm 0.28 \mathrm{nmol} / \mathrm{mg}$ of total lipoprotein mass (LDL, seven preparations). This corresponds to a molar ratio of $0.27 \pm 0.12$ and $9.3 \pm 0.70 \mathrm{~mol}$ of $\alpha \mathrm{TocH} / \mathrm{mol}$ of $\mathrm{HDL}_{3}$ and LDL respectively, which is comparable with other reports $[13,35]$.

\section{Uptake of $\mathrm{HDL}_{3}$-associated $\alpha \mathrm{TocH}$ by HepG2 cells}

The following experiments were designed to establish whether mass transfer of $\mathrm{HDL}_{3}$-associated $\alpha \mathrm{TocH}$ occurred when HepG2 cells were cultured in the presence of FCS, an external

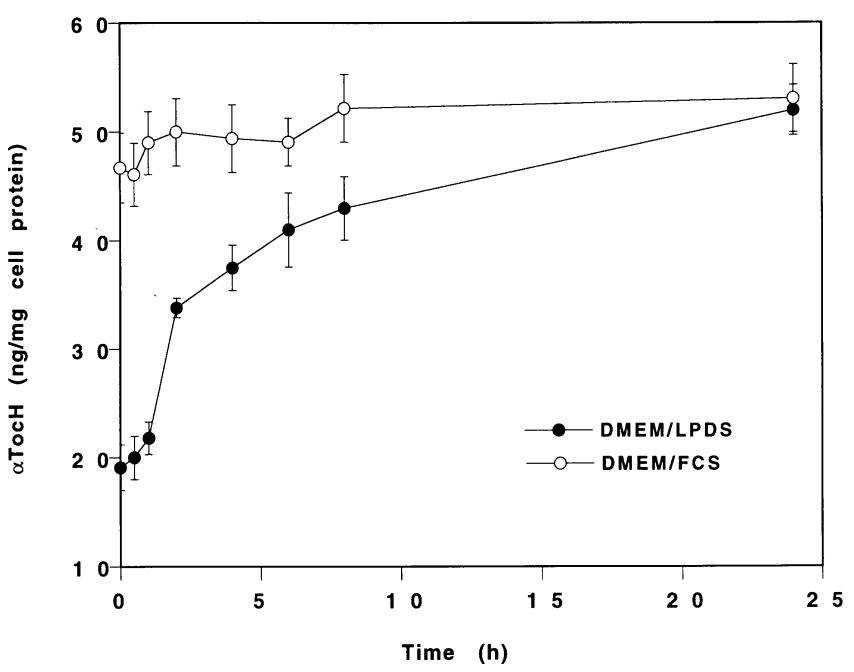

Figure 1 Uptake of unlabelled $\mathrm{HDL}_{3}$-assocated $\alpha$ TocH by HepG2 cells

Near-confluent (80-90\%) HepG2 cells were cultured on $60 \mathrm{~mm}$ Petri dishes. Before the uptake experiment, cells were incubated in DMEM containing $10 \%(\mathrm{v} / \mathrm{v})$ FCS $(\mathrm{O})$ or $10 \%(\mathrm{v} / \mathrm{v})$ LPDS (O). At time zero, the cells received $3 \mathrm{ml}$ of DMEM supplemented with unlabelled $\mathrm{HDL}_{3}$ (131 $\mu \mathrm{g}$ of protein; $250 \mathrm{ng}$ of $\alpha \mathrm{ToCH})$ and LPDS $(10 \%, \mathrm{v} / \mathrm{v})$. At the indicated time points, cells were washed and cellular lipids were extracted with hexane/propan-2-ol $(3: 2, \mathrm{v} / \mathrm{v})$. The cellular lipid extracts were dried under argon and analysed for $\alpha \mathrm{TocH}$ content by HPLC with fluorescence detection as described in the Experimental section. The cellular residues were lysed in $\mathrm{NaOH}(0.3 \mathrm{M})$ and analysed for protein content. The data are means \pm S.D. from triplicate dishes from one representative experiment. 


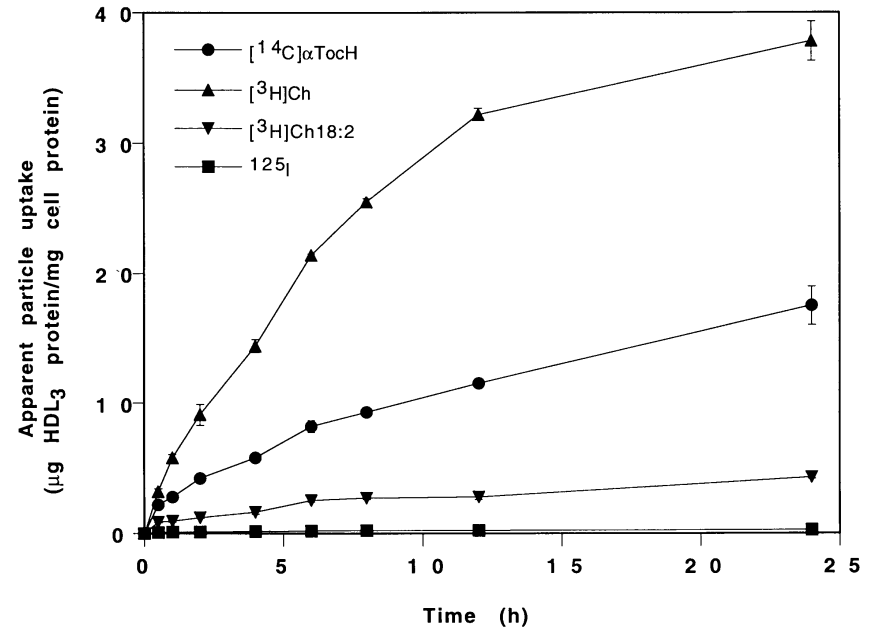

Figure $2 \mathrm{HDL}_{3}$ holoparticle and particle-independent lipid uptake by HepG2 cells

HepG2 cells were cultured in DMEM containing $10 \%$ (v/v) FCS on $35 \mathrm{~mm}$ Petri dishes until confluence. At $12 \mathrm{~h}$ before the uptake studies, cells were cultivated in DMEM containing 10\% LPDS. Cells were washed with PBS and received fresh medium (LPDS) containing $50 \mu \mathrm{g}$ of $\mathrm{HDL}_{3}$ protein/ml labelled with $\left.\left.\mathrm{Na}^{125}(\boldsymbol{\square}),{ }^{14} \mathrm{C}\right] \alpha \mathrm{TocH}(\boldsymbol{O}),{ }^{3} \mathrm{H}\right] \mathrm{Ch} 18: 2(\boldsymbol{\nabla})$ or $\left[{ }^{3} \mathrm{H}\right] \mathrm{Ch}(\boldsymbol{\Delta})$. At the indicated time points, cells were washed twice with TBS/BSA and then twice with TBS. Aliquots of $0.3 \mathrm{M} \mathrm{NaOH}$ lysates were used to measure protein content and cell-associated radioactivity. To allow comparison of tracer uptake on the same basis, results were calculated as apparent particle uptake (i.e. the amount of protein that would account for the observed tracer uptake, if uptake were mediated by holoparticle uptake). Holoparticle uptake $\left({ }^{125}-\mathrm{HDL}_{3}\right)$ represents the sum of cell-associated and degraded $\mathrm{HDL}_{3}$. The data are means \pm S.D. from triplicate dishes from one representative experiment.

source of $\alpha \mathrm{TocH}$. The $\alpha \mathrm{TocH}$ concentration in FCS ranged from 0.2 to $2.8 \mu \mathrm{M}$ (four different batches analysed), a concentration that could suffice to saturate the cellular $\alpha$ TocH pool. Under these experimental conditions, one would expect exchange rather than net mass transfer during radiotracer experiments. To clarify this, HepG2 cells were incubated in DMEM containing either FCS $(1.15 \mu \mathrm{M} \alpha \mathrm{TocH})$ or heat-inactivated LPDS devoid of $\alpha \mathrm{TocH}$. After this preconditioning period, the cells received DMEM containing LPDS and $\mathrm{HDL}_{3}$. At the indicated time points, cells were washed and the cellular lipids were analysed for their $\alpha \mathrm{TocH}$ content. Data from these experiments are shown in Figure 1. It is evident that the $\alpha \mathrm{TocH}$ content of HepG2 cells precultured in DMEM containing FCS remained almost constant over the entire $24 \mathrm{~h}$ incubation period ( 46.7 and $53.1 \mathrm{ng} / \mathrm{mg}$ of cell protein at 0 and $24 \mathrm{~h}$ respectively). In contrast, cultivation of HepG2 cells in DMEM containing LPDS resulted in a significant reduction in cellular $\alpha \mathrm{TocH}$ content when compared with DMEM/FCS conditions $(19.1 \pm 2.1$ and $46.7 \pm 3.2 \mathrm{ng} / \mathrm{mg}$ of cell protein respectively). Incubation in the presence of $\mathrm{HDL}_{3}$ increased the cellular $\alpha \mathrm{TocH}$ content from $20.0(0.5 \mathrm{~h})$ to $52.0 \mathrm{ng} / \mathrm{mg}$ of cell protein $(24 \mathrm{~h})$. These experiments demonstrate rapid and quantitative net mass transfer of $\mathrm{HDL}_{3}$-associated $\alpha \mathrm{TocH}$ to HepG2 cells.

To investigate $\alpha \mathrm{TocH}$-uptake mechanisms by HepG 2 cells, the lipid moiety of $\mathrm{HDL}_{3}$ was labelled with $\left[{ }^{14} \mathrm{C}\right] \alpha \mathrm{TocH}$ and the protein moiety was labelled with $\mathrm{Na}^{125}$ I. These experiments were performed to compare the efficacy of $\alpha \mathrm{TocH}$ uptake with that of $\left[{ }^{3} \mathrm{H}\right] \mathrm{Ch}$ and $\left[{ }^{3} \mathrm{H}\right] \mathrm{Ch} 18: 2$, tracers known to be taken up via the selective uptake pathway [36]. Data from time-dependent experiments are shown in Figure 2 and are expressed in terms of apparent $\mathrm{HDL}_{3}$ particle uptake as suggested [31]. The time-

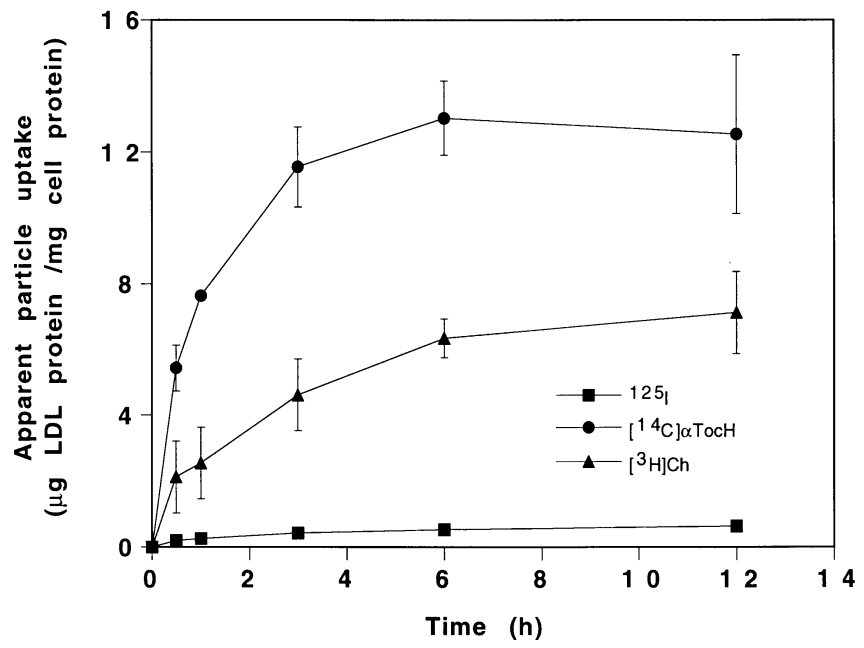

Figure 3 LDL holoparticle and particle-independent lipid uptake by HepG2 cells

Cells were cultured as described in the legend to Figure 2. Preincubation was performed in DMEM containing LPDS $12 \mathrm{~h}$ before the uptake experiment. Cells were then incubated in the presence of $100 \mu \mathrm{g} \mathrm{LDL}$ protein labelled with $\mathrm{Na}^{125}(\boldsymbol{\square}),\left[{ }^{3} \mathrm{H}\right] \mathrm{Ch}(\boldsymbol{\Delta})$ or $\left[{ }^{14} \mathrm{C}\right] \alpha \mathrm{TocH}(\mathbf{O})$ At the indicated time points, cells were washed and lysed by $\mathrm{NaOH}$ treatment. An aliquot was used to measure cellular protein content, and the remainder was used to determine cellassociated radioactivity. To allow comparison of tracer uptake on the same basis, results were calculated as apparent particle uptake (i.e. the amount of protein that would account for the observed tracer uptake, if uptake were mediated by holoparticle uptake). Holoparticle uptake $\left({ }^{125} \mathrm{I}-\mathrm{LDL}\right)$ represents the sum of cell-associated and degraded LDL. The data are means \pm S.D. from triplicate dishes from one representative experiment.

dependent uptake of ${ }^{125} \mathrm{I}_{-} \mathrm{HDL}_{3}$ (expressed as sum of binding, internalization and degradation) displayed saturation kinetics, the plateau value being reached within $8 \mathrm{~h}(0.21 \pm 0.013 \mu \mathrm{g}$ of $\mathrm{HDL}_{3}$ protein $/ \mathrm{mg}$ of cell protein). In contrast, incubation of $\mathrm{HepG} 2$ cells in the presence of $\left[{ }^{14} \mathrm{C}\right] \alpha \mathrm{TocH}-$ labelled $\mathrm{HDL}_{3}$ resulted in a constant increase in cell-associated radioactivity from 2.2 to $17.5 \mu \mathrm{g}$ of $\mathrm{HDL}_{3} / \mathrm{mg}$ of cell protein $(2$ and $24 \mathrm{~h}$ respectively). $\alpha \mathrm{TocH}$ uptake was very efficient and exceeded that of $\mathrm{HDL}_{3}$ holoparticle by 83 -fold $(17.5 \mu \mathrm{g}$ and $0.21 \mu \mathrm{g}$ respectively) after $24 \mathrm{~h}$. For comparative reasons, cells were incubated in the presence of $\left[{ }^{3} \mathrm{H}\right] \mathrm{Ch} 18: 2$-labelled $\mathrm{HDL}_{3}$, a tracer known to be delivered to HepG2 cells via the selective uptake pathway [36]. $\left[{ }^{3} \mathrm{H}\right] \mathrm{Ch} 18: 2$ uptake was also significantly higher (e.g. 6.2- and 20fold at 6 and $24 \mathrm{~h}$ ) than $\mathrm{HDL}_{3}$ holoparticle uptake over the entire time course investigated. The most efficient particle-independent uptake was displayed by $\mathrm{HDL}_{3}$-associated $\left[{ }^{3} \mathrm{H}\right] \mathrm{Ch}$; at the $24 \mathrm{~h}$ time point, uptake of $\left[{ }^{3} \mathrm{H}\right] \mathrm{Ch}$ exceeded $\mathrm{HDL}_{3}$ holoparticle uptake by 180 -fold. From the results shown in Figure 2, it is evident that $\mathrm{HDL}_{3}$-associated $\alpha \mathrm{TocH}$ is delivered to HepG2 cells independently of holoparticle uptake with high efficiency.

To study further whether LDL-associated $\alpha$ TocH is taken up to a greater extent than LDL particles, HepG2 cells were incubated in the presence of ${ }^{125} \mathrm{I}-\mathrm{LDL}$ or $\left[{ }^{14} \mathrm{C}\right] \alpha \mathrm{T}$ ocH-labelled LDL. As shown in Figure 3, the time-dependent uptake of $\alpha$ TocH exceeded LDL-particle uptake at all time points investigated. Both $\alpha$ TocH uptake and LDL-particle uptake were saturable processes, reaching a plateau after $6 \mathrm{~h}$. At the $12 \mathrm{~h}$ time point, $\alpha$ TocH uptake exceeded ${ }^{125}$ I-LDL uptake by a factor of 28 $(12.5 \pm 2.4$ and $0.46 \pm 0.014 \mu \mathrm{g} / \mathrm{mg}$ of cell protein respectively), demonstrating that LDL-associated $\alpha \mathrm{TocH}$ also underwent particle-independent uptake in HepG2 cells. The efficacy of LDL-associated cholesterol uptake was about 11 times lower 


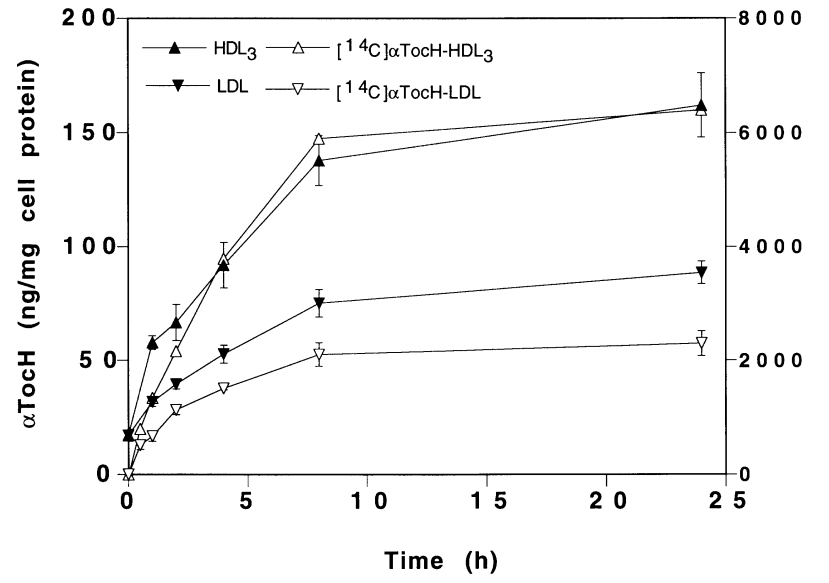

Figure 4 Comparison of $\alpha \mathrm{TocH}$ mass transfer and tracer uptake

Cells were cultured as described in the legend to Figure 2 and cultured in DMEM containing LPDS $12 \mathrm{~h}$ before the uptake experiment. Uptake studies with radiolabelled lipoproteins were performed in six-well trays, and, for mass-transfer studies, cells were cultured in $100 \mathrm{~mm}$ Petri dishes. The lipoprotein concentrations were chosen on the basis of equal $\alpha$ TocH concentrations present as either $\mathrm{HDL}_{3}$ - or $\mathrm{LDL}$-associated $\alpha \mathrm{TocH}$. Transfer of radiolabelled $\alpha \mathrm{TocH}$ : cells were incubated in the presence of $\left[{ }^{14} \mathrm{C}\right] \alpha \mathrm{TocH}-$ labelled $\mathrm{HDL}_{3}(150 \mu \mathrm{g}$ of protein; $296 \mathrm{ng}$ of endogenous $\alpha \mathrm{TocH}$; specific radioactivity $177 \mathrm{c.p.m} . / \mathrm{ng}$ of endogenous $\alpha \mathrm{TocH})$ and $\left[{ }^{14} \mathrm{C}\right] \alpha \mathrm{TocH}$-labelled LDL (15 $\mu \mathrm{g}$ of protein; $309 \mathrm{ng}$ of endogenous $\alpha \mathrm{TocH}$; specific radioactivity 184 c.p.m./ng of endogenous $\alpha \mathrm{TocH}$ ). At the indicated time points the cells were washed and cellular radioactivity was counted in $\mathrm{NaOH}$ lysates. The data are means \pm S.D. from triplicate dishes from one representative experiment. Transfer of endogenous $\alpha \mathrm{TocH}$ ('mass transfer'): cells were incubated in the presence of unlabelled $\mathrm{HDL}_{3}(2.2 \mathrm{mg}$ of protein; $2.5 \mu \mathrm{g}$ of endogenous $\alpha \mathrm{TocH}$ ) and LDL (0.20 mg of protein; $2.5 \mu \mathrm{g}$ of endogenous $\alpha \mathrm{TocH})$ in $4 \mathrm{ml}$ of DMEM containing LPDS. At the indicated time points, the cells were washed and the cellular lipids were extracted with hexane/propan-2-ol. The organic extracts were dried under argon, redissolved in $110 \mu$ l of methanol and analysed by HPLC as described in the Experimental section. The cellular residue was lysed in $3 \mathrm{ml}$ of $0.3 \mathrm{M} \mathrm{NaOH}$ to measure protein content.

than uptake of $\mathrm{HDL}_{3}$-associated cholesterol (Figures 2 and 3; total $/$ particle uptake $=180$ and 15.7 for $\mathrm{HDL}_{3}$ - and LDLassociated cholesterol respectively).

A major question arising from the results shown in Figures 2 and 3 was whether $\mathrm{HDL}_{3}-$ and LDL-associated $\alpha$ TocH are transferred at the same rates and with the same efficacy. In addition, we wanted to clarify whether uptake of $\left[{ }^{14} \mathrm{C}\right] \alpha \mathrm{TocH}$ was by mass transfer or merely exchange. To allow a comparison of these results, HepG2 cells were incubated in the presence of $\mathrm{HDL}_{3}$ and $\mathrm{LDL}$ adjusted for equal concentrations of radioactive and/or unlabelled (endogenous) $\alpha \mathrm{TocH}$. At the indicated time points, cells were washed and analysed for their $\alpha \mathrm{TocH}$ content by liquid-scintillation counting or HPLC analysis of the cellular lipid extracts. From the data shown in Figure 4, it is apparent that the amount of $\left[{ }^{14} \mathrm{C}\right] \alpha \mathrm{T}$ ocH delivered by $\mathrm{HDL}_{3}$ exceeded that transferred via LDL at all time points analysed. This effect was most pronounced after $24 \mathrm{~h}$ when $\mathrm{HDL}_{3}$-mediated $\left[{ }^{14} \mathrm{C}\right] \alpha \mathrm{TocH}$ transfer was approx. 3-fold higher than that mediated by LDL (6400 c.p.m. and 2300 c.p.m./mg of cell protein respectively). The same effect was observed when HepG2 cells were incubated in the presence of unlabelled $\mathrm{HDL}_{3}$ or LDL. After a $24 \mathrm{~h}$ incubation period, cells acquired $162 \mathrm{ng}$ of $\alpha \mathrm{TocH} / \mathrm{mg}$ of cell protein during an incubation in the presence of $2.5 \mu \mathrm{g}$ of $\mathrm{HDL}_{3}-$ associated $\alpha \mathrm{TocH}$. In contrast, when cells were incubated in the presence of LDL containing an equal amount of $\alpha \mathrm{TocH}$, the corresponding value was only $88 \mathrm{ng} / \mathrm{mg}$ of cell protein, indicating that $\alpha \mathrm{TocH}$ associated with $\mathrm{HDL}_{3}$ is transferred with greater efficiency than LDL associated with $\alpha \mathrm{TocH}$ (Figure 4). In
Table 1 Effect of metabolic inhibitors on $\left[{ }^{14} \mathrm{C}\right] \alpha \mathrm{TocH}$ - and ${ }^{125}$ I-labelled $\mathrm{HDL}_{3}$ uptake by HepG2 cells

Cells were preconditioned in DMEM containing 10\% LPDS before the addition of the metabolic inhibitors. Cells then received fresh medium containing LPDS (10\%) with the indicated concentrations of the various inhibitors (added as aqueous stock solutions) for the time indicated before the addition of $100 \mu \mathrm{g}$ of $\left[{ }^{14} \mathrm{C}\right] \alpha \mathrm{ToCH}-\mathrm{HDL}_{3}$ or ${ }^{125} \mathrm{I}-\mathrm{HDL}_{3}$ protein. After $6 \mathrm{~h}$, cells were washed as described in the Experimental section, and lysed in $\mathrm{NaOH}$. Aliquots of the lysate were used to measure radioactivity $(800 \mu \mathrm{l})$ and cell protein $(60 \mu \mathrm{l})$. Results are means \pm S.D. for three determinations from one representative experiment. ${ }^{*} P<0.05$ compared with control.

\begin{tabular}{llr}
\hline & $\begin{array}{l}\text { Apparent } \mathrm{HDL}_{3} \text { particle uptake } \\
(\% \text { of control } \dagger)\end{array}$ \\
\cline { 2 - 2 } Inhibitor & {$\left[{ }^{14} \mathrm{C}\right] \alpha \mathrm{TocH}-\mathrm{HDL}_{3}$} & ${ }^{125} \mid-\mathrm{HDL}_{3}$ \\
\hline Control & $100 \pm 5.2$ & $100 \pm 6.8$ \\
Monensin $(5 \mu \mathrm{M} ;$ overnight $)$ & $102 \pm 7.9$ & $103 \pm 5.1$ \\
Colchicine $(1 \mu \mathrm{M} ; 120 \mathrm{~min})$ & $102 \pm 3.4$ & $95 \pm 7.2$ \\
Acrylamide $(5 \mathrm{mM} ; 360 \mathrm{~min})$ & $117 \pm 0.5^{*}$ & $111 \pm 4.5$
\end{tabular}

$\dagger 100 \%$ corresponds to an (apparent) particle uptake of $18.6 \pm 0.97$ and $0.6 \pm 0.04 \mathrm{ng}$ of $\mathrm{HDL}_{3} / \mathrm{mg}$ of cell protein for $\left[{ }^{14} \mathrm{C}\right] \alpha \mathrm{TocH}-\mathrm{HDL}_{3}$ and ${ }^{125} /-\mathrm{HDL}_{3}$ respectively.

addition, these results indicate that the radiolabelled $\alpha \mathrm{TocH}$ was transferred in conjunction with endogenous lipoproteinassociated $\alpha$ TocH.

\section{Effects of Golgi and cytoskeletal inhibitors on the uptake of $\mathrm{HDL}_{3}$ - associated $\alpha \mathrm{TocH}$}

To determine to what extent different metabolic inhibitors interfere with uptake of $\left[{ }^{14} \mathrm{C}\right] \alpha \mathrm{TocH}-\mathrm{HDL}_{3}$ and holoparticle uptake of ${ }^{125} \mathrm{I}-\mathrm{HDL}_{3}$, HepG2 cells were incubated in the presence of the indicated concentrations of several metabolic inhibitors (Table 1) and the correspondingly labelled $\mathrm{HDL}_{3}$ preparation. In these experiments, we used monensin (interferes with intracellular lipid transport [37]), colchicine (interferes with microtubule assembly but also disrupts Golgi membranes [38]) and acrylamide (interferes with intermediate filament action [38]). Acrylamide produced significantly enhanced $\alpha$ TocH uptake (1.12-fold, $P<$ $0.05)$, but monensin and colchicine were without effect. Holoparticle uptake was not affected by any of the metabolic inhibitors used here.

\section{Effect of ATPase inhibitors on the uptake of $\mathrm{HDL}_{3}$-associated $\alpha \mathrm{TocH}$}

To test whether ATPases are involved in $\alpha$ TocH internalization, the effect of three V-type ATPase inhibitors (bafilomycin A, $\mathrm{NaN}_{3}$ and $\mathrm{KNO}_{3}$ [39]) and two P-type ATPase inhibitors (molybdate and vanadate [38]) on $\alpha$ TocH uptake was investigated. None of these ATPase inhibitors affected the cellular capacity for $\alpha$ TocH uptake (Table 2).

\section{Effect of the cellular cholesterol content on the uptake of $\mathrm{HDL}_{3}$ - associated $\alpha \mathrm{TocH}$}

Both SR-BI expression and selective uptake of HDL-associated CEs have been demonstrated to be regulated by the cellular/tissue cholesterol content $[36,40]$. To test the possibility that uptake of HDL-associated $\alpha$ TocH is also modulated by cellular cholesterol content, HepG 2 cells were cultivated in the absence or presence 
Table 2 Effect of various ATPase inhibitors on $\left[{ }^{14} \mathrm{C}\right] \alpha \mathrm{TocH}$ uptake by HepG2 cells

HepG2 cells were preconditioned in DMEM containing 10\% LPDS (12 h) followed by a 60 min incubation in the presence of the indicated concentrations of ATPase inhibitors which were added in Hanks balanced salt solution. Cells were washed and placed in fresh Hanks balanced salt solution (containing $100 \mu \mathrm{g}$ of $\left[{ }^{14} \mathrm{C}\right] \alpha \mathrm{TocH}-\mathrm{HDL}_{3}$ protein). After $120 \mathrm{~min}$ of incubation, cells were washed and lysed by the addition of $1 \mathrm{ml}$ of $0.3 \mathrm{M} \mathrm{NaOH}$. Aliquots of the lysate were used to measure radioactivity $(800 \mu l)$ and cell protein $(60 \mu l)$. Results are means \pm S.D. for three determinations from one representative experiment.

\begin{tabular}{llr}
\hline & \multicolumn{2}{c}{$\left[{ }^{14} \mathrm{C}\right] \alpha \mathrm{TocH}-\mathrm{HDL}_{3}$} \\
\cline { 2 - 3 } Inhibitor & $\mu \mathrm{g} / \mathrm{mg}$ of cell protein & $\%$ of control \\
\hline None (control) & $19.4 \pm 1.85$ & 100 \\
Bafilomycin $\mathrm{A}(250 \mathrm{nM})$ & $19.7 \pm 0.98$ & $101 \pm 5.1$ \\
$\mathrm{KNO}_{3}(50 \mathrm{mM})$ & $21.7 \pm 0.94$ & $112 \pm 4.8$ \\
$\mathrm{NaN}_{3}(1 \mathrm{mM})$ & $20.4 \pm 1.56$ & $105 \pm 8.1$ \\
$\left(\mathrm{NH}_{4}\right)_{2} \mathrm{VO}_{3}(50 \mu \mathrm{M})$ & $18.8 \pm 0.62$ & $97 \pm 3.2$ \\
$\mathrm{Na}_{2} \mathrm{MoO}_{4}, 2 \mathrm{H}_{2} \mathrm{O}(250 \mu \mathrm{M})$ & $19.8 \pm 1.66$ & $102 \pm 8.5$ \\
\hline
\end{tabular}

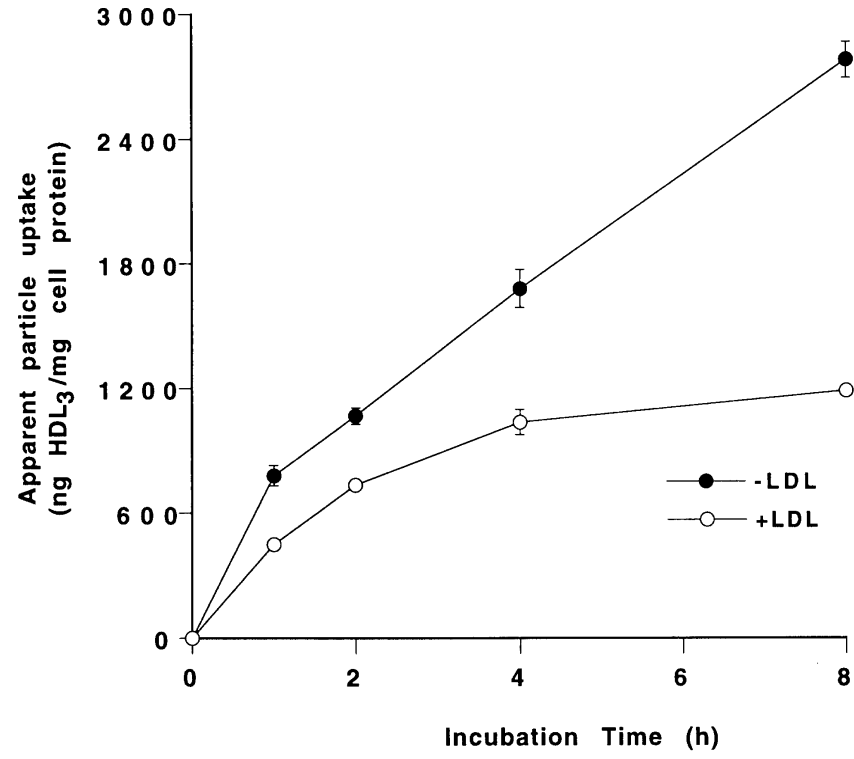

Figure 5 Effect of cellular cholesterol content on $\left[{ }^{14} \mathrm{C}\right] \alpha \mathrm{TocH}-\mathrm{HDL}_{3}$ uptake

To modify the cellular cholesterol content, HepG2 cells were incubated on $35 \mathrm{~mm}$ Petri dishes in the absence $(\mathbf{)}$ ) or presence $(O)$ of LDL (1.5 mg of total lipoprotein mass) for $15 \mathrm{~h}$ in DMEM/LPDS. Thereafter the cells were washed and incubated in DMEM/LPDS containing $25 \mu \mathrm{g}$ of $\left[{ }^{14} \mathrm{C}\right] \alpha \mathrm{TocH}$-labelled $\mathrm{HDL}_{3}$. At the indicated time points, the cells were washed and cellular radioactivity was counted in $\mathrm{NaOH}$ lysates. An aliquot was used to measure cellular protein content. Results are expressed as apparent particle uptake. The data are means \pm S.D. from triplicate dishes from one representative experiment.

of LDL (1.5 mg of total lipoprotein mass/well). The latter incubation resulted in an increase in total cholesterol content from $28 \mu \mathrm{g}$ (control) to $60 \mu \mathrm{g} / \mathrm{mg}$ of cell protein, in line with earlier reports [36]. After the incubation in the absence or presence of LDL, HepG2 cells were incubated in the presence of $25 \mu \mathrm{g}$ of $\left[{ }^{14} \mathrm{C}\right] \alpha \mathrm{TocH}$-associated $\mathrm{HDL}_{3}$. When cells were preincubated in the absence of LDL, the apparent particle uptake was $2781 \pm 87 \mathrm{ng}$ of $\mathrm{HDL}_{3} / \mathrm{mg}$ of cell protein (Figure 5). In contrast, preincubation in the presence of LDL resulted in apparent particle uptake of $1190 \pm 12 \mathrm{ng}$ of $\mathrm{HDL}_{3} / \mathrm{mg}$ of cell protein. Therefore a 2 -fold increase in total cell cholesterol
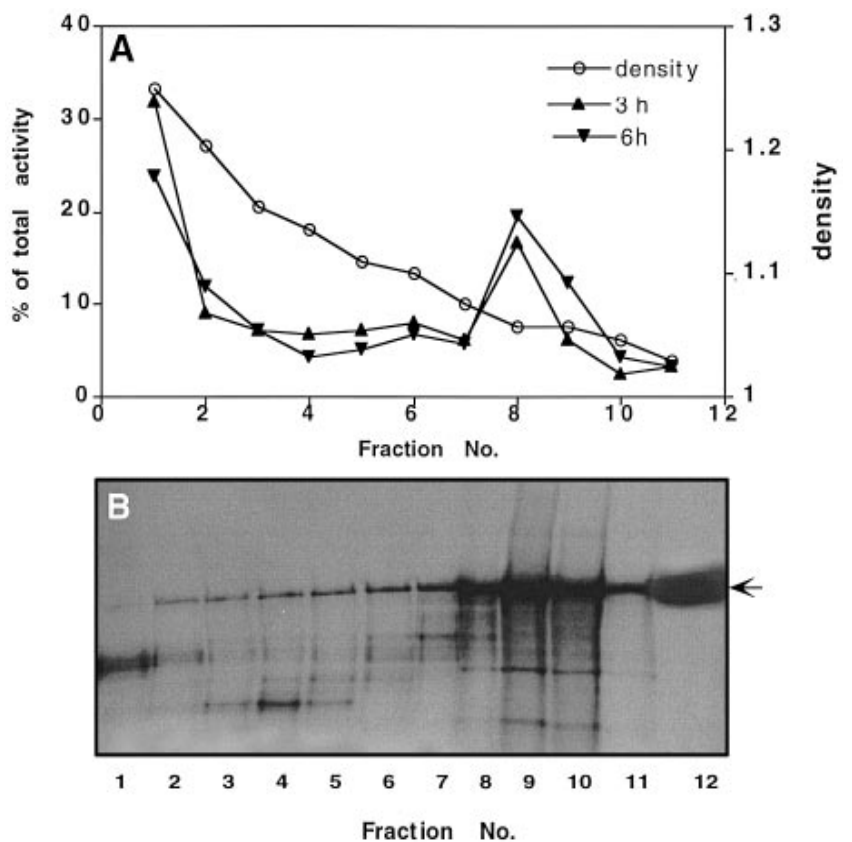

Figure $6 \alpha \mathrm{TocH}$ delivered to HepG2 cells is resecreted in newly synthesized apoB-100-containing lipoprotein

(A) Confluent HepG2 cells were cultured on $60 \mathrm{~mm}$ Petri dishes in DMEM containing LPDS before the uptake experiments. Cells received fresh medium containing $500 \mu \mathrm{g}$ of $\left[{ }^{14} \mathrm{C}\right] \alpha \mathrm{TocH}$ labelled $\mathrm{HDL}_{3}$ which was left on the cells for $2 \mathrm{~h}$. Cells were washed with TBS/BSA and TBS and subsequently treated with $2 \mathrm{ml}$ of a $0.05 \%$ trypsin solution for $5 \mathrm{~min}$ at $37^{\circ} \mathrm{C}$. Then $3 \mathrm{ml}$ of DMEM $/ 10 \%$ LPDS was added to the Petri dishes and left for 3 and $6 \mathrm{~h}$. The cellular supernatant was then removed, adjusted to a density of $1.24 \mathrm{~g} / \mathrm{ml}$ and subjected to ultracentrifugation in a discontinuous $\mathrm{KBr}$ gradient in an SW-41 swing-out-bucket rotor as described in the Experimental section. The gradient fractions were down-loaded from the top of the tube and transferred to preweighed Eppendorf tubes to estimate the density of the single fractions. Radioactivity present in the down-loaded fractions was then determined. Results are means from two experiments. (B) In a parallel incubation, HepG2 cells were preincubated in

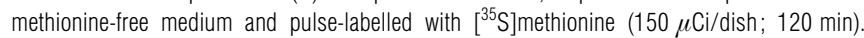
ApoB-100 in the gradient fractions recovered from the density gradient (lanes 1-11) was immunoprecipitated as described in the Experimental section and separated by SDS/PAGE (3-7\% gels). Bands were visualized by autoradiography. The arrow indicates the position of ${ }^{125}$-labelled apoB-100 used as a standard (lane 12).

resulted in a 2.3 -fold decrease in $\left[{ }^{14} \mathrm{C}\right] \alpha \mathrm{TocH}$ uptake, in line with observations for selective uptake of HDL-associated CEs [36].

\section{Resecretion of internalized $\alpha \mathrm{TocH}$ with newly synthesized lipoproteins}

HepG2 cells are known to synthesize and secrete apoB-100containing LDL-like particles, also termed LpB100 [32,33]. We therefore examined whether $\alpha$ TocH internalized by HepG2 cells independently of holoparticles is assembled with newly synthesized lipoproteins and resecreted. HepG 2 cells were metabolically labelled in the presence of $\left[{ }^{14} \mathrm{C}\right] \alpha \mathrm{TocH}-\mathrm{HDL}_{3}$. They were then washed and subjected to a short treatment with trypsin to remove membrane-bound lipoprotein particles. After 3 and $6 \mathrm{~h}$ the cellular supernatant was aspirated, subjected to densitygradient ultracentrifugation, and the radioactivity present in the single fractions was counted. These experiments indicated that resecretion of $\alpha \mathrm{TocH}$ by $\mathrm{HepG} 2$ cells was quite efficient, i.e. within $3 \mathrm{~h}$ nearly $50 \%$ of the radioactivity associated with HepG2 cells after the trypsin treatment (time zero of chase) was found in the cellular supernatant $(7200 \pm 1136$ and $15540 \pm$ 1789 c.p.m. secreted and cell-associated radioactivity respectively 


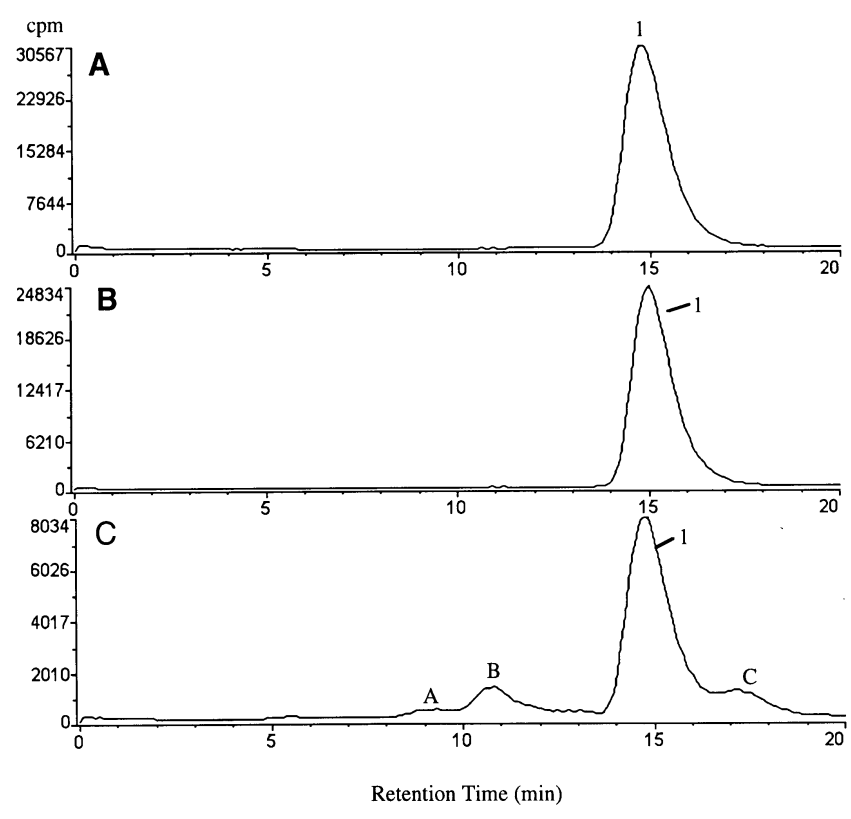

Figure 7 Radiometric HPLC analysis of cellular and resecreted $\left[{ }^{14} \mathrm{C}\right] \alpha \mathrm{TocH}$

Cells were cultivated as described in Figure 6(A). Radiometric HPLC analysis of extracted $\left.\left[{ }^{14} \mathrm{C}\right] \alpha \mathrm{TocH}\right]$ (metabolites) was performed as described in the Experimental section. A $20 \mu \mathrm{l}$ volume of the corresponding lipid extract was analysed. (A) Analysis of lipid extracts from $\left.\left[{ }^{14} \mathrm{C}\right] \alpha \mathrm{TocH}-\mathrm{HDL}_{3} .{ }^{14} \mathrm{C}\right] \alpha \mathrm{TocH}-\mathrm{HDL}_{3}(50 \mu)$ was extracted in hexane/methanol $(5: 1, \mathrm{v} / \mathrm{v}$; $10 \mathrm{ml})$; the hexane phase was aspirated, dried and redissolved in $400 \mu \mathrm{l}$ of mobile phase. (B) Analysis of cellular lipid extracts after a $120 \mathrm{~min}$ pulse period in the presence of $500 \mu \mathrm{g}$ of $\left[{ }^{14} \mathrm{C}\right] \alpha \mathrm{TocH}-\mathrm{HDL}_{3}$. For these experiments cells were labelled as described in Figure $6(\mathrm{~A})$. Cellular lipids were extracted into hexane/propan-2-ol (3:2, v/v; $4 \mathrm{ml})$, and the extracts were dried under nitrogen and redissolved in $400 \mu \mathrm{l}$ of mobile phase. (C) Analysis of $\left[{ }^{14} \mathrm{C}\right] \alpha \mathrm{TocH}$ resecreted into the medium during a $3 \mathrm{~h}$ chase period. Pulse-chase experiments were performed as described in Figure 6(A). The medium was removed and subjected to densitygradient ultracentrifugation in an SW-41 rotor as described in the Experimental section. The density fraction 1.04-1.075 g/ml was removed and extracted with hexane. The hexane phase was aspirated, dried under nitrogen and redissolved in $250 \mu \mathrm{l}$ of mobile phase.

at time zero of chase). Analysis of the gradient fractions revealed that $40 \%$ of the resecreted radioactivity was recovered in a density region between 1.046 and $1.074 \mathrm{~g} / \mathrm{ml}$, very similar to the buoyant density of LDL-like lipoprotein particles secreted by HepG2 cells (Figure 6A). The remaining activity was found in the top $(\approx 5 \%, 1.03-1.046 \mathrm{~g} / \mathrm{ml})$ and the bottom of the gradient at a density of $1.16-1.25 \mathrm{~g} / \mathrm{ml}(40-50 \%)$. The distribution of resecreted $\alpha \mathrm{TocH}$ in the density gradient obtained after a $6 \mathrm{~h}$ chase was not significantly different from the results obtained after $3 \mathrm{~h}$ (Figure 6A). These data indicate that some of the $\alpha \mathrm{TocH}$ delivered to HepG2 cells was resecreted (and assembled) with endogenously synthesized LDL-like particles.

In parallel experiments, HepG2 cells were pulse-labelled with $\left[{ }^{35} \mathrm{~S}\right]$ methionine to clarify whether newly synthesized apoB- 100 and resecreted $\left[{ }^{14} \mathrm{C}\right] \alpha \mathrm{TocH}$ are co-localized in the density gradient. Cells were then chased with methionine-containing medium, and the chase medium was subjected to ultracentrifugation followed by immunoprecipitation of apoB-100 and subsequent autoradiography. Ultracentrifugation and immunoprecipitation of apoB-100 in the density fractions obtained from $\left[{ }^{35} \mathrm{~S}\right]-$ methionine-pulse-labelled HepG2 cells revealed that most of the apoB-100 was present in fractions $8-10$ in a density interval between 1.029 and $1.069 \mathrm{~g} / \mathrm{ml}$, corresponding to the LDL-like fraction secreted by HepG2 cells (Figure 6B). The results presented in Figure 6(A) and 6(B) demonstrate that some of the $\alpha \mathrm{TocH}$ internalized by $\mathrm{HepG} 2$ cells was resecreted with a lipoprotein fraction floating in a density region between 1.046 and $1.074 \mathrm{~g} / \mathrm{ml}$ and co-localized with most of the apoB-100 produced by endogenous synthesis.

To confirm that $\alpha$ TocH was still in its bioactive reduced state, both the cellular lipids and the lipids resecreted into the medium were extracted and analysed by reversed-phase HPLC with radiometric detection (Figures $7 \mathrm{~A}-7 \mathrm{C}$ ). Figure $7(\mathrm{~A})$ shows the elution pattern of $\left[{ }^{14} \mathrm{C}\right] \alpha \mathrm{TocH}-\mathrm{HDL}_{3}$ lipid extracts and it is evident that $\left[{ }^{14} \mathrm{C}\right] \alpha \mathrm{TocH}$ is eluted as a single peak (peak 1, coeluted with an unlabelled standard; not shown). To test the effect of cellular uptake on the tracer, cells were incubated for $120 \mathrm{~min}$ in the presence of $\left[{ }^{14} \mathrm{C}\right] \alpha \mathrm{TocH}-\mathrm{HDL}_{3}$, washed and the cellular lipids extracted and analysed. As can be seen from Figure 7(B), the elution pattern of the cell-associated label is identical with peak 1 shown in Figure 7(A). Another set of Petri dishes was then chased for $3 \mathrm{~h}$ and analysed for the secreted tracer. Figure 7(C) demonstrates the occurrence of three new peaks with shorter (peaks A and B) and slightly longer (peak C) retention times compared with $\left[{ }^{14} \mathrm{C}\right] \alpha \mathrm{TocH}$. These newly occurring $\alpha \mathrm{TocH}-$ derived compounds contribute approx. $15-20 \%$ of the total peak area in Figure 7(C) after the $3 \mathrm{~h}$ incubation in the presence of HepG2 cells.

\section{DISCUSSION}

We present evidence that particle-independent uptake of $\mathrm{HDL}_{3}$ associated $\alpha \mathrm{TocH}$ is compatible with the concept of selective uptake described for HDL-associated CEs: (i) the efficacy of particle-independent uptake of $\alpha \mathrm{TocH}$ is dependent on the size of the donor particle; (ii) cellular cholesterol content regulates the efficiency of $\mathrm{HDL}_{3}$-associated $\alpha \mathrm{TocH}$ uptake, in analogy with reports for selective uptake of HDL-associated CEs [36] and SR-BI expression [40]. The tissue distribution of $\alpha \mathrm{TocH}$ in rats provides further indirect support for the assumption that HDL-associated $\alpha \mathrm{TocH}$ is taken up selectively: Bjornboe and colleagues [41] reported that rat adrenal glands, one of the major sites of SR-BI expression [19] and selective HDL-CE uptake in vivo [42], contain the highest $\alpha \mathrm{TocH}$ concentrations (on a per gram of tissue basis).

The efficacy of lipoprotein particle-independent uptake of $\mathrm{HDL}_{3}$-associated $\alpha \mathrm{TocH}$ was higher than that of $\mathrm{Ch} 18: 2$, but lower than holoparticle-independent uptake of non-esterified cholesterol, which probably reflects the lipid polarity and/or the topographical location of the lipids within a lipoprotein particle. Most Ch18:2 is expected to reside within the hydrophobic $\mathrm{HDL}_{3}$ core [43], whereas $\alpha \mathrm{TocH}$ and cholesterol are located in the polar surface layer [20], a fact that may contribute to the greater efficiency of selective uptake, as observed in the present study. We also observed lipoprotein-particle-independent uptake of LDL-associated $\alpha \mathrm{TocH}$, in line with in vivo findings reported by Cohn et al. [11]. These authors have reported greater uptake of LDL-associated $\alpha$ TocH than lipoprotein particles by a variety of tissues in Watanabe heritable hyperlipidaemic and control rabbits.

A remarkable observation in the present study is that LDLassociated $\alpha$ TocH was less readily taken up than HDL-associated $\alpha \mathrm{TocH}$, a fact that should be considered during supplementation studies. This observation may be a result of the larger lipid core of the LDL particle, acting as a sink for $\alpha$ TocH and thereby decreasing the probability of diffusion out of the particle [44]. On the other hand, the greater curvature of the $\mathrm{HDL}_{3}$ particle may contribute to the higher transfer rates, comparable with observations reported for selective HDL-associated CE uptake [45]. The in vivo relevance of apoA-containing lipoproteins during 
$\alpha \mathrm{TocH}$ turnover has been demonstrated in patients suffering from abetaliproteinaemia. These patients are unable to synthesize apoB-containing lipoproteins because of a defect in the microsomal triacylglycerol transfer protein [46]. When supplemented with vitamin $\mathrm{E}$, some of these patients can achieve normal adipose-tissue tocopherol levels [47], which is compatible with our results.

To identify possible routes for selective uptake and/or storage of $\alpha \mathrm{TocH}$, different metabolic inhibitors were studied; most had no significant effect on uptake by HepG2 cells (Table 1). ATPase inhibitors were also without effect on selective $\alpha$ TocH uptake (Table 2), in line with data reported for selective uptake of HDLassociated CEs [38]. Reaven and colleagues [38] have demonstrated that $N$-ethylmaleimide (NEM) efficiently blocks internalization of HDL-associated fluorescently labelled CE derivatives. In accordance with a more general role of NEM as an inhibitor of selective lipid uptake, Fielding and Fielding [48] demonstrated that selective uptake of LDL-associated cholesterol is blocked by NEM. In line with these reports, we have observed a slight inhibition of $\alpha \mathrm{TocH}$ uptake by HepG2 cells in the presence of NEM (D. Goti and W. Sattler, unpublished work). From our data, it appears unlikely that NEM-sensitive fusion protein, an ATPase that triggers the break-up of soluble NEM-sensitive factor attachment protein receptor complexes [49], is involved in $\alpha \mathrm{TocH}$ uptake/internalization, since bafilomycin and $\mathrm{KNO}_{3}$ failed to interfere with selective uptake of HDL-associated $\alpha \mathrm{TocH}$.

In analogy with selective uptake of HDL-associated CEs [36], the present study reveals an inverse relationship between HDLparticle-independent $\alpha$ TocH uptake and intracellular cholesterol content. Although this does not provide direct evidence for selective $\alpha$ TocH uptake via SR-BI-mediated mechanisms, our observations are at least compatible with such a concept, since SR-BI expression is regulated by the cellular cholesterol content [40]. Increased cellular $\alpha \mathrm{TocH}$ concentrations (as a result of the LDL preincubation) could be an alternative explanation for the observed down-regulation of selective HDL- $-\alpha$ TocH uptake, although this appears to be less likely. Preincubation of mouse adrenal Y-1 cells (expressing SR-BI) with cholesterol-supplemented medium resulted in significantly down-regulated HDL $-\alpha$ TocH uptake, comparable with effects observed in the presence of LDL (results not shown). We are at present clarifying whether the decrease in selective $\alpha$ TocH uptake on LDL loading is a result of increased cholesterol concentrations or a combined effect of increased intracellular cholesterol and $\alpha \mathrm{TocH}$ content.

In rats, about $90 \%$ of total $\alpha$ TocH is associated with the liver, adipose tissue and skeletal muscle [41]. Most of the intracellular $\alpha \mathrm{TocH}$ in these animals is found in mitochondria, the endoplasmic reticulum and the Golgi apparatus [50]. The confinement of $\alpha \mathrm{TocH}$ to the endoplasmic reticulum and Golgi apparatus could be important for the association with newly synthesized VLDL, since the endoplasmic reticulum is the organelle where the first steps of intracellular VLDL assembly occur [51]. Lipoprotein synthesis in HepG2 cells is a sequential process starting with the co-translational integration of apoB100 into the membrane of the endoplasmic reticulum and subsequent transfer from the site of synthesis to the site of assembly, where it interacts with neutral lipids to form lipoprotein particles [32,33]. It is tempting to speculate that the endoplasmic reticulum may also be the intracellular compartment where $\alpha \mathrm{TocH}$ is assembled with newly synthesized lipoproteins. Our pulse-chase and metabolic $\left[{ }^{35} \mathrm{~S}\right]$ methionine-labelling experiments demonstrate that originally $\mathrm{HDL}_{3}$-associated $\alpha \mathrm{TocH}$, selectively taken up by HepG2 cells, can be resecreted along with newly synthesized apoB-100-containing lipoproteins, with most of the label located in an LDL-density-like fraction and the dense region of the gradient (Figure 6A). At present, it is not clear whether the fraction of $\alpha \mathrm{TocH}$ that is present in the dense region of the gradient is associated with a carrier protein. Preliminary experiments have revealed that most of this label is associated with a $60-90 \mathrm{kDa}$ fraction eluted from a size-exclusion column (E. Malle and W. Sattler, unpublished work). Also the site of assembly with apoB-100-containing lipoproteins is not clear; it could be achieved by the action of the $\alpha$ TocH-transfer/binding protein [6]. Independently of the mechanism(s) responsible for $\alpha \mathrm{TocH}$ assembly/association with newly synthesized lipoproteins, selective uptake and subsequent hepatic resecretion could contribute to the maintenance of circulating concentrations. Selective uptake of HDL-associated $\alpha \mathrm{TocH}$ could also precede biliary secretion of circulating $\alpha$ TocH or the more polar oxidized metabolites, e.g. $\alpha$-tocopherylquinone [27].

In summary, our findings demonstrate that uptake of HDLassociated $\alpha$ TocH occurs via a particle-independent (selective) uptake pathway; selective uptake was not inhibited by the ATPase inhibitors tested but was regulated by cellular cholesterol content, in line with findings for SR-BI expression [40]. Finally, HDL-associated $\alpha$ TocH taken up selectively is incorporated and resecreted with newly synthesized lipoproteins. Whether selective uptake affects $\alpha \mathrm{TocH}$-mediated signal-transduction pathways via modulation of protein kinase activity [34] remains to be elucidated.

This work was supported by grants P12000 MED (to W. S.) and P11276 MED (to E. M.) from the Austrian Research Foundation (F.W. F.), the Franz-Lanyar Stiftung and the Austrian National-Bank (projects 6232 to W.S. and 5677 to E. M.). D. G. received financial support from the International Federation of Medical Students Associations Standing Committee on Elective Exchange. $\left[{ }^{14} \mathrm{C}\right] \alpha \mathrm{TocH}$ was a gift from Dr. Steiling (Henkel Co, Dusselfdorf, Germany).

\section{REFERENCES}

1 Ingold, K. U., Burton, G. W., Foster, D. O. and Hughes, L. (1990) Free Radic. Biol. Med. 9, 205-210

2 Niki, E. (1987) Chem. Phys. Lipids 44, 227-253

3 Muller, D. P. R. (1995) Redox Rep. 1, 239-245

4 Guggenheim, M. A., Ringel, S. P. and Silverman, A. (1982) Ann. N.Y. Acad. Sci. 393, 84-95

5 Traber, M. G., Burton, G. W., Ingold, K. U. and Kayden, H. J. (1990) J. Lipid Res. 31, 675-685

6 Traber, M. G. (1994) Free Radic. Biol. Med. 16, 229-239

7 Kostner, G. M., Oettl, K., Jauhiainen, M., Ehnholm, C., Esterbauer, H. and Dieplinger, H. (1995) Biochem. J. 305, 659-667

8 Traber, M. G., Burton, G. W., Hughes, L., Ingold, K. U., Hidaka, H., Malloy, M., Kane, J., Hyams, J. and Kayden, H. J. (1992) J. Lipid Res. 32, 1171-1182

9 Stein, O., Halperin, G., Leitersdorf, E., Olivecrona, T. and Stein, Y. (1984) Biochim. Biophys. Acta 795, 47-59

10 Sattler, W., Levak-Frank, S., Radner, H., Kostner, G. M. and Zechner, R. (1996) Biochem. J. 318, 15-19

11 Cohn, W., Goss-Sampson, M. A., Grun, H. and Muller, D. P. R. (1992) Biochem. J. 287, 247-254

12 Steinbrecher, U., Zhang, H. and Lougheed, M. (1990) Free Radic. Biol. Med. 9, 155-168

13 Dieber-Rotheneder, M., Puhl, H., Waeg, G., Striegl, G. and Esterbauer, H. (1991) J. Lipid Res. 32, 1325-1332

14 Bowry, V. and Stocker, R. (1993) J. Am. Chem. Soc. 115, 6029-6044

15 Cohn, W., Gross, P., Grun, H., Loechleitner, F., Muller, D. P. R. and Goss-Sampson, M. A. (1993) in Vitamin E: Its Usefulness in Health and Curing Diseases (Mino, M., ed.), pp. 95-102, Japan Science Press, Tokyo, S. Karger, Basel

16 Eisenberg, S. (1984) J. Lipid Res. 25, 1017-1058

17 Marotti, K. R., Castle, C. K., Boyle, T. P., Lin, A. H., Murray, R. W. and Melchior, G. W. (1993) Nature (London) 364, 73-75

18 Goldberg, D. I., Beltz, W. F. and Pittmann, R. C. (1991) J. Clin. Invest. 87, 331-346

19 Acton, S. L., Rigotti, A., Landschultz, K. T., Xu, S., Hobbs, H. and Krieger, M. (1996) Science 271, 518-520

20 Granot, E., Tamir, I. and Deckelbaum, R. J. (1988) Lipids 23, 17-21

21 Sattler, W., Mohr, D. and Stocker, R. (1994) Methods Enzymol. 233, 469-489 
22 Schumaker, V. N. and Puppione, D. L. (1986) Methods Enzymol. 128, 155-170

23 Goldstein, J. L., Basu, S. K. and Brown, M. S. (1983) Methods Enzymol. 98, $241-260$

24 Sattler, W. and Stocker, R. (1993) Biochem. J. 294, 771-778

25 Sinn, H. J., Schrenk, H. H., Friedrich, E. A., Via, D. P. and Dresel, H. A. (1988) Anal. Biochem. 170, 186-192

26 Sattler, W, Reicher, H., Ramos, P., Panzenboeck, U., Hayn, M., Esterbauer, H., Malle, E. and Kostner, G. M. (1996) Lipids 31, 1303-1310

27 Vatassery, G. T. and Smith, W. E. (1987) Anal. Biochem. 167, 411-417

28 Aden, D. P., Fogel, A., Plotkin, S., Damjanov, I. and Knowles, B. B. (1979) Nature (London) 282, 615-616

29 Lowry, O. H., Rosebrough, N. J., Farr, A. L. and Randall, R. J. (1951) J. Biol. Chem. 193, 265-275

30 Panzenboeck, U., Wintersperger, A., Levak-Frank, S., Zimmermann, R., Zechner, R., Kostner, G. M., Malle, E. and Sattler, W. (1997) J. Lipid Res. 38, 239-253

31 Pittman, R. C., Knecht, T. P., Rosenbaum, M. S. and Taylor, C. A. (1987) J. Biol. Chem. 262, 2443-2450

32 Wettesten, M., Boström, K., Bondjers, G., Jarfeldt, M., Norfeldt, P. I., Carrella, M., Wiklund, 0., Boren, J. and Olofsson, S. O. (1985) Eur. J. Biochem. 149, 461-466

33 Boren, J., Wettesten, M., Sjöberg, A., Thorlin, T., Bondjers, G., Wiklund, 0. and Olofsson, S. 0. (1990) J. Biol. Chem. 265, 10556-10564

34 Boscoboinik, D., Szwczyk, A., Hensey, C. and Azzi, A. (1991) J. Biol. Chem. 266 6188-6194

35 Bowry, V. W., Stanley, K. K. and Stocker, R. (1992) Proc. Natl. Acad. Sci. U.S.A. 89 $10316-10320$
36 Rinninger, F. and Pittman, R. C. (1988) J. Lipid Res. 29, 1179-1194

37 Mendez, A. J. (1995) J. Biol. Chem. 270, 5891-5900

38 Reaven, E., Tsai, L. and Azhar, S. (1996) J. Biol. Chem. 271, 16208-16217

39 Crider, B. P., Xie, X. S. and Stone, D. K. (1994) J. Biol. Chem. 269, 17379-17381

$40 \mathrm{Ng}$, D. S., Francone, O. L., Forte, T. M., Zhang, J., Haghpassand, M. and Rubin, E. M. (1997) J. Biol. Chem. 272, 15777-15781

41 Bjornboe, A., Bjornboe, G. E. A., Bodd, E., Hagen, B. F., Kveseth, N. and Drevon, C. A. (1986) Biochim. Biophys. Acta 889, 310-315

42 Glass, C., Pittman, R. C., Civen, M. and Steinberg, D. (1985) J. Biol. Chem. 260 $744-750$

43 Miller, K. W. and Small, D. M. (1983) J. Biol. Chem. 258, 13772-13784

44 Traber, M. G., Lane, J. C., Lagmay, N. R. and Kayden, H. J. (1992) Lipids 27, $657-663$

45 Pittman, R. C., Glass, C. K., Atkinson, D. and Small, D. (1987) J. Biol. Chem. 262 , 2435-2442

46 Sharp, D., Blinderman, L., Combs, K. A., Kienzle, B., Ricci, B., Wager-Sith, K., Gil, C. M., Turck, C. W., Bouma, M. E., Rader, D. J., Aggerbeck, L. P., Gregg, R. E. Gordon, D. A. and Wetterau, J. R. (1993) Nature (London) 365, 65-68

47 Kayden, H. J., Hatam, L. J. and Traber, M. G. (1983) J. Lipid Res. 24, 652-656

48 Fielding, C. J. and Fielding, P. E. (1995) Biochemistry 34, 14237-14244

49 Rothman, J. E. and Warren, G. (1994) Curr. Biol. 4, 220-233

50 Hagen, B. F., Bjornboe, A., Bjornboe, G. E. A. and Drevon, C. A. (1989) Alcohol. Clin. Exp. Res. 13, 246-251

51 Gibbons, G. F. (1990) Biochem. J. 268, 1-13

Received 25 November 1997/20 January 1998; accepted 2 February 1988 